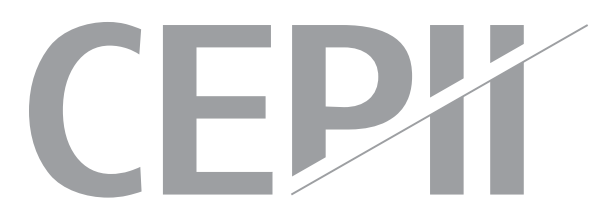

\title{
Non-Tariff Measures, Specific Trade Concerns and Tariff Reduction
}

Gianluca Orefice

\section{Highlights}

- This paper studies whether Specific Trade Concerns are raised by exporting countries as a consequence of tariff reductions in importing countries (when non-tariff measures become barriers to trade).

- Results show that Specific Trade Concerns on SPS and TBT are raised when the underlying NTM becomes a barrier to trade, i.e. when tariff protection lowers.

- We find that a tariff reduction implying a $10 \%$ lower tariff-inclusive price corresponds to a $0.18 \%$ and $0.36 \%$ higher probability of observing a STC on SPS and TBT respectively. 


\section{Abstract}

This paper studies the determinants of the recent proliferation of Specific Trade Concerns raised at the WTO on Non-tariff Trade Measures (NTMs), with a focus on Sanitary and Phyto Sanitary (SPS) and Technical Barriers to Trade (TBT). Even thought NTMs are de jure imposed to protect consumers from unhealthy products, they de facto increase trade costs. So, when tariff protection lowers, NTMs become effective barriers to trade and the exporting countries can complain at the dedicated committee at the WTO (STCs). Therefore we study whether STCs are raised by exporting countries as a consequence of tariff reductions in importing countries, i.e. when non-tariff measures become barriers to trade. Using a recent database on STCs over the period 1996-2010, we find empirical evidence that SPS and TBT concerns are raised by exporting country as a consequence of importer's tariff cut.

\section{Keywords}

International Trade, Tariffs, Non-tariff Measures, Specific Trade Concerns.

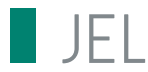

F13, F14, F53

\section{Working Paper}

CEPII (Centre d'Etudes Prospectives et d'Informations Internationales) is a French institute dedicated to producing independent, policyoriented economic research helpful to understand the international economic environment and challenges in the areas of trade policy, competitiveness, macroeconomics, international finance and growth.
CEPII Working Paper

Contributing to research in international economics

(c) CEPII, PARIS, 2015

All rights reserved. Opinions expressed in this publication are those of the author(s) alone.

$\begin{array}{ll}\text { Editorial Director: } & \text { CEPII } \\ \text { Sébastien Jean } & 113, \text { rue de Grenelle } \\ & 75007 \text { Paris } \\ \text { Production: } & +33153685500 \\ \text { Laure Boivin } & \\ \text { No ISSN: } 1293-2574 & \text { www.cepii.fr }\end{array}$




\title{
Non-Tariff Measures, Specific Trade Concerns and Tariff Reduction
}

\author{
Gianluca Orefice*
}

\section{Introduction}

"The issue today is with the difficulties involved in trade opening. Domestic trade politics have become more difficult and trade deals have become more complex because the nature of obstacles to trade has evolved. We are no longer negotiating just the reduction of tariffs, but also of non-tariff barriers, which have gained enormous importance." (Pascal Lamy, former DG of the WTO 24 July 2013)

In the farewell statement to the General Council of the WTO on 24 July 2013, Pascal Lamy highlighted the changing nature of barriers to trade: from tariff to non-tariff measures. ${ }^{1}$ In this respect, the World Trade Report 2012 depicted a clear positive trend in the proliferation of NonTariff Measures (NTMs) as revealed by WTO data on notifications showing increasing use of TBT/SPS measures since the mid-1990' (see World Trade Report 2012 section C). In the same period, the worldwide tariff protection reduced thanks to the proliferation of Preferential Trade Agreements: from 70 PTAs in 1990 to 300 PTAs in 2010 (see Figure B1 of the World Trade Report 2011). The raise of NTMs and the contemporaneous reduction in tariff protection suggest the potential role of NTMs in affecting trade: even though the average tariff level is now quite low (4.4\% in manufacturing in 2010$)^{2}$, the level of the overall protection revealed by cross border ad valorem equivalent tariff is still very high (more than $100 \%$ according to De Sousa et al. 2012). This confirms the increasing role of non-tariff measures in affecting market access.

NTMs are de jure imposed to protect consumers for unhealthy or low quality products, ${ }^{3}$ but de facto they represent an increase in trade costs. ${ }^{4}$ When tariff protection is high, non-tariff

\footnotetext{
CEPII, rue de Grenelle 113, 75007 Paris (France). Email : gianluca.orefice@cepii.fr. I am grateful to Agnes Chevallier, Houssein Guimbard, Lionel Fontagné, Sebastien Jean, Sophie Piton and participants to CEPII seminar for useful comments and suggestions. The views expressed in this article are those of the author and do not reflect the institution. The usual disclaimers apply.

${ }^{1}$ According to the UNCTAD definition "Non-tariff measures (NTMs) are policy measures, other than ordinary customs tariffs, that can potentially have economic effect on international trade in goods, changing quantities traded, or prices or both". 2 TRAINS data.

${ }^{3}$ Non-tariff measures are often the first-best instruments to achieve public policy objectives and consumer protection (as correcting market failures from information asymmetries and imperfect competition). NTMs may also stimulate trade by providing more information about a given good or by improving the characteristics of the good itself (Maertens et al. 2007; Maertens and Swinnen 2009). Crivelli and Gröschl (2012) show that conformity assessment SPS measures constitute a
} 
measures are "latent" barriers to trade, but when tariff protection lowers, such measures become effective barriers to trade and the exporter country can raise a concern at the dedicated SPS and TBT committees of the WTO. Then a Specific Trade Concern (STC) at the WTO is activated. We use STCs dataset to test whether STCs are raised by exporting countries when the non-tariff measure becomes a barrier to trade, i.e. when tariff protection becomes lower (tariff reduction). Indeed, a pre-existing measure (initially "innocuous" because of high tariff protection) becomes trade constraining only after a reduction in the applied bilateral tariff. In this case the exporter country will likely raise a concern at the WTO (activating a STC). Alternatively, when tariff protection is already low and further tariff reduction is experienced, the government can impose a new non-tariff measure to compensate for the tariff cut. ${ }^{5}$ Also in this last circumstance the exporting country is likely to raise a STC. By using STC data we cannot directly isolate these two channels, i.e. we cannot differentiate between pre-existing or new NTM (nevertheless, in Section 4 we propose an indirect way to isolate the two channels). However the main purpose of this paper is documenting the determinants of STCs on new or pre-existing NTMs with a particular focus on tariff protection and tariff cuts. Moreover, disentangling the real motivations behind the imposition of a NTM is beyond the ambition of the paper. We leave aside any interpretation of the welfare effect of NTMs. ${ }^{6}$

The idea that STCs are raised when non-tariff measures are effective barriers to trade (when tariff cut reveals "latent" NTMs or when measures are imposed to compensate tariff cut) is motivated by the timing of some STCs raised at the SPS and TBT committees of the WTO. ${ }^{7}$ AS an example, China in 2003 raised a concern at the WTO (SPS committee) complaining about a non-tariff measure imposed by the European Union on natural honey (HS code 0409): the EU

barriers to trade (extensive margins), while STCs related to product characteristics increase trade flows after that exporters (in the exporting country) meet the new standard (intensive margin).

NTMs may increase both variable and/or fixed trade costs. On one hand, this might act as entry barrier affecting only the export participation of firms (leaving unchanged the intensive margin of incumbent firms). On the other hand, NTMs might affect the variable trade cost also for incumbent firms and reduce accordingly the aggregated trade flows. In a recent paper Fontagné et al. (2015) show that the presence of SPS measure reduces the value of export by $21 \%$. Similarly, by using data on 619 firms in 17 developing countries, Chen et al. (2006) find that testing procedures imposed by potential destination countries reduce export shares by $19 \%$.

5 Low tariff protection, by allowing foreign low-efficient producers to enter the market with low-quality goods, pushes the domestic government to impose NTMs. See Beverelli et al.(2014) on the trade policy substitution argument.

${ }^{6}$ NTMs may not imply economic inefficiencies and their welfare effect strongly depends on the specific type of the measure (i.e. standards, border inspection policies, labeling, etc) and on the type of market imperfection they correct.

Specific Trade Concerns are cases raised by a complaining country against a NTM imposing country at the SPS/TBT committees of the WTO. Data on STCs are provided by the WTO. See section 2 for further details. 
restricted the imports of natural honey from China as a food safety measure due to the presence of a toxic antibiotic (chloramphenicol) in Chinese honey. ${ }^{8}$ The consumers' protection aim of this measure is clear, but the timing of such NTM imposition is important and evoking. This concern was indeed raised the year before the EU enlargement towards the Eastern European countries in 2004. Interestingly, among the new EU member states, Poland and Slovenia had in 2003 a high tariff protection on Chinese honey (applied tariff on natural honey respectively 89 and $45 \%)^{9}$ - to be necessarily reduced the year after with the accession to the $\mathrm{EU}$ at $17.3 \%$ (EU tariff protection on honey). ${ }^{10}$ Identifying the causal relationship between the EU enlargement and the imposition of NTM on Chinese honey would be extremely hard and definitely falls outside the aim of the present paper. But it contributes to motivate the empirical question analyzed in this paper: do STCs match observed or expected tariff reductions?

In April 2008, Ecuador (supported in raising the concern by Costa Rica) noted its concern about possible modification of the EU maximum residue levels for Ethephon, particularly in pineapple (HS code 0804). ${ }^{11}$ Such SPS measure hindered the exports of pineapple from these Latin American countries to the EU. Interestingly, this concern was raised by Ecuador just after the access of Romania in the common market (2007). Up to 2005 the tariff protection imposed by Romania on pineapple coming from Ecuador was 23.3\%, and expected to be completely removed in two years (EU has zero tariff protection in pineapple coming from Ecuador). Also this example motivates the empirical question analyzed here: are SPS concerns raised after tariff reductions?

These circumstances do not involve only the European Union agriculture sector, many other countries have raised STCs on SPS and TBT just after a consistent reduction in the applied tariff level. For example the Republic of Korea in 2003 raised a concern at the TBT committee against China for a conformity assessment measure imposed in many products of the HS chapter 84 (Boiler). ${ }^{12}$ This TBT concern was raised after a consistent reduction in the Chinese applied tariff level on products coming from Korea in the HS sectors 8477 and 8479 (machinery

\footnotetext{
8 See the document G/SPS/R/30.

${ }^{9}$ TRAINS data on effectively applied tariff (defined as the lowest available tariff between preferential and MFN). Notice that TRAINS provides the Ad Valorem Equivalents of non Ad Valorem Tariff. See section 2 for details.

${ }^{10}$ Poland is one of the top destinations for Chinese exports of honey. Over the period 1998-2009 Poland experienced an average annual growth of honey imports from China by 140\% (see Wei et al. 2012, Tab 3).

${ }^{11}$ See document G/SPS/R/49.

12 See document G/TBT/N/CHN/13.
} 
for working rubber or plastics and taps, cocks, valves and similar appliances). Over the period 2001-2003 the Chinese applied tariff for product HS 8477 (coming from Korea) passed from $14.1 \%$ to $5.2 \%$; while it passed from $14 \%$ to $6.6 \%$ in the HS code 8479 . Thus it seems that concerns on NTMs are raised after a period characterized by large tariff reduction.

Descriptive evidence supports the anecdotal evidence reported above. Figures 1 and 2 show a strong decline in the average applied tariff level over the period 1996-2010 and an increase in the number of STCs on SPS and TBT (approximated by the number of HS-4 digit lines targeted by SPS/TBT concerns by at least one country- as revealed by STCs dataset): countries complain at the WTO when tariff protection reduces and NTMs become barriers to trade. The same kind of evidence is shown in Figures $A 1$ and $A 2$ where we report the correlation between the average tariff change and the change in the number of SPS and TBT concerns by HS-4 digit headings over the period 1996-2010. For the SPS concerns we find a clear negative correlation: HS-4 heading with high tariff reductions experienced high increases in the number of SPS concerns (Figure A1). The evidence is less clear for TBT concerns, Figure A2, where null correlation is shown between average tariff changes and the average increase in the number of TBT concerns. ${ }^{13}$ However the econometric exercise reported in section 4 clearly shows the relation between tariff cuts and STCs also for TBTs. In the last decade both the number of countries and products targeted by STCs increased consistently (Table 1). In the period 20002010 the number of countries targeted in at least one Specific Trade Concern increased by $96 \%$ for SPS, and by $216 \%$ for TBT; while the number of products (HS-4 digit codes) targeted in at least one STC increased by $13 \%$ for SPS and by $201 \%$ for TBT. In the same period, developing countries have reduced the number of HS-4 digit lines for which they have been targeted in SPS concerns, and increased the number of HS-4 digit lines for which they have been targeted in TBT concerns. This is not the case for developed countries that, over the same period have consistently increased the number of products for which they have been targeted by STCs on SPS and TBT. This heterogeneity across countries (regions) in NTMs concerns will be explored in the econometric exercise below (section 4.2).

In this paper we aim to test the role of tariff reduction on the probability of raising a NTM concern, we therefore rely on the list of Specific Trade Concerns raised at the WTO in the

\footnotetext{
${ }^{13}$ In the vertical axis of Figures A1 and A2 we report the average yearly tariff change by HS-4 headings (period 1996-2010); while in the horizontal axis we report the average change in the number of STCs by HS-4 headings (on SPS and TBT respectively).
} 
period 1995-2010. The idea is that a country complains against a measure at the WTO if the measure represents an effective barrier to trade for its exporters. Being based on STCs raised at the SPS and TBT committees of the WTO, this database contains information on: (i) technical barriers to trade (TBT) regarding standards for manufactured goods and (ii) sanitary and phytosanitary (SPS) measures concerning food safety and animal/plant health, and domestic regulation in services. ${ }^{14}$ The main advantage of the STC database is that we can track the single concern (and the underlying NTM) over the period of interest with a homogeneous product classification (HS-4 digit rev. 1992). ${ }^{15}$ For this reason we can adopt a panel data approach to estimate the probability of having an active bilateral Trade Specific Concern over the period $1996-2010 .^{16}$ To do so, tracking the single measure over time is fundamental. This is not the first paper using STCs data, Fontagné et al. (2015) and Crivelli and Gröschl (2012) used STCs dataset to test the effect of NTBs on trade. Beverelli et al. (2014) use STCs data to test the trade policy substitution between tariff and non tariff measures, ${ }^{17}$ their study is focused on uncovering possible instances of protectionist use of NTMs in explaining the trade policy determinants of (importer) countries. While here we are primarily interested in explaining the recent increase in Specific Trade Concerns raised at the SPS and TBT committees of the WTO.

Existing literature on NTMs focuses mainly on their effect on trade (Kee et al. 2009; Disdier et al. 2008; Cadot et al. 2014; Chen 2006) ${ }^{18}$ and only a limited number of studies have been

\footnotetext{
${ }^{14}$ Notice that SPS and TBT are only part of the all possible non-tariff measures that a country can impose. Technical measures are also pre-shipment inspection formalities. Under the chapter of non-technical measure, there is a variety of measures that might affect trade (such as contingent trade protection measure, price control measures, distribution restriction, etc). SPS measures refer to measures affecting areas such as restriction for substances and measures for preventing dissemination of diseases, but also conformity assessment measures related to food safety. TBT refers to measures such as labeling and all those measures protecting the environment, standard on technical specifications and quality requirement.

${ }^{15}$ This is not the case for other NTMs datasets based on comprehensive list of measures (TRAINS and Perinorm), they do not track the single measure over time, implying important limitations for the empirical strategy (no panel data approach). Moreover, other datasets based on comprehensive list of NTMs mix up trade deterring with trade unaffecting measures.

16

17 We lose the 1995 because tariff data are not available in 1995.

Beverelli et al. (2014) find clear evidence of trade policy substitutability: countries impose NTMs to compensate reductions in imposed applied tariff (imposing country specific approach). As a difference with respect to Beverelli et al. (2014), in this paper we are interested in the exporting country's perspective: we study whether STCs are raised by exporting countries when they face the erosion of market access into a specific destination (country pair specific approach).

Kee et al.(2009) using cross section data on 91 countries for 4575 (HS 6 digit) products, estimate a 12\% Ad Valorem Equivalent effect of core NTMs. Disdier et al.(2008) find that TBT and SPS significantly reduce developing countries' exports to OECD countries but do not affect intra OECD countries trade. The effect of standard harmonization on trade flows
} 
conducted on the determinants of NTMs imposition. Ray (1981) shows that both tariff and nontariff (US) protection focus on industries in which the United States have no comparative advantage vis-à-vis the rest of the world. Ray (1981) provides evidence that non-tariff restrictions are used to supplement tariffs: tariff and non-tariff protection go hand in hand, suggesting a kind of complementarity between the two types of protectionist policies. Conversely, Mansfield and Busch (1995), by using cross country OECD data, find that industries with initial high tariff levels have lower non-tariff protection: preexisting tariff levels influence both the lobbies' demand for NTMs and the willingness by policy makers to meet such demand. Industries already highly protected by tariffs exert weak pressure for further non-tariff protection and would face more policy maker resistance to new NTMs than low protected industries. This suggests that tariffs and non-tariff protection are indeed substitutes. More recently, Kee et al. (2009) test the substitutability between tariff and the Ad Valorem Equivalent (AVE) of NTMs using cross-section data for 91 countries. They find that, after controlling for country and sector fixed effects, tariff and (core) NTMs are substitutes to each other. In particular a $10 \%$ higher AVE of core NTMs is associated to a $0.3 \%$ lower tariff (see Kee et al. 2009, Table 2). Beverelli et al. (2014) show the trade policy substitutability between tariff and non-tariff measures.

This paper contributes to the existing literature for several aspects. First, we focus on STCs, namely, on the probability that an exporter country complains at the WTO on a new/existing NTM imposed by a destination country. We do this by using panel data approach thanks to STC dataset (existing literature on the determinants of NTMs is mostly based on pure cross section analysis). Second, we exploit the bilateral dimension of STCs data. This enables us: (i) to examine the peculiarities in STCs formation by degree of development of countries (i.e. northnorth vs. north-south, etc.) and (ii) to control properly in estimations for any country-sector specific productivity or demand shock that might guide the trade policy of a country (we use country-sector-year fixed effects). ${ }^{19}$ Third, we provide evidence of Specific Trade Concerns rising by type of measure, indeed, both SPS and TBT concerns might refer to specific health protection measure, quality standard or environment related measures. Concerns on each type

\footnotetext{
depends also on regional vs international harmonization. Cadot et al.(2011) show that regional standard harmonization reduces North-South trade, but this effect is offset by international standards harmonization.

19

This is crucial since a negative productivity or demand shock in a given country-sector, might induce the country to complain about a measure or to impose a new measure on the sector experiencing the negative productivity shock.
} 
of measure might be differently affected by tariff cuts. We show clear cut evidence that exporting countries raise a STC when their trade partner reduced the applied tariff for imports, so when the underlying SPS/TBT measure becomes a trade barriers with protectionist effect.

The rest of the paper is organized as follows. The next section describes the dataset. Section 3 presents the empirical strategy, while section 4 describes the results. Final section concludes.

\section{Data}

To study whether tariff reductions have an effect on non-tariff measure concerns (STCs), this paper combines two major databases: (i) a recent database on specific trade concerns (STCs) raised at the SPS and TBT committees at WTO, and (ii) applied tariff database from TRAINS.

STCs database has been released by the $\mathrm{WTO}^{20}$ and relies on the work undertaken in the context of SPS and TBT committees of the WTO. These two committees provide WTO members with a forum to discuss issues related to SPS and TBT measures (imposed by other members) that might have significant effect on trade. These issues are referred to as Specific Trade Concerns (STCs) and contain information about the product covered by the measure, the type of measure and the objective of the measure. When a country raises a concern at the SPS Committee over a measure, it specifies also the product of concern and the issue. The STCs dataset provides information of NTMs at HS-4 digit product classification. In other words, if at least one product within the HS-4 heading is object of a concern, the STCs dataset registers the measure for the overall heading HS-4. For this reason in what follows HS-4 heading and products are used as synonymous.

The STCs database contains information on: (i) the country or countries raising the concern and the country imposing the measure, (ii) the product codes (HS-4 digit) involved in the concern, (iii) the year in which the concern has been raised to the WTO, (iv) whether it has been resolved and (v) the information on the primary subject of the concern (e.g. human or animal health, environment protection etc). Once the lists of STCs on SPS and TBT are put in a panel data format, the two datasets contain raising-imposing-product combinations experiencing at least one SPS/TBT measure over the period 1995-2010. The virtue of the STCs datasets is that we can follow the single concern over time, from rising to resolution. This is crucial for the type of

\footnotetext{
${ }^{20}$ This is available at http://www.wto.org/english/res e/publications e/wtr12 dataset e.htm in a quantitative format and in a searchable format in http://spsims.wto.org/web/pages/search/stc/Search.aspx.
} 
panel analysis we conduct here (see section 3) that cannot be replicated by using other NTM databases based on comprehensive list of NTMs (which cannot be tracked over time). Then, the SPS and TBT databases have been combined with tariff data from TRAINS database.

TRAINS database contains information on the effectively applied tariffs (defined as the lowest available tariff between preferential and MFN) at HS-6 digit product aggregation in the period 1996-2010. However, to be consistent with the STCs datasets, we need tariffs at HS-4 digit. To this end, we use HS-4 digit tariff data as simple average tariff within HS-4 headings (this aggregation is directly provided by TRAINS). ${ }^{21}$ After the merge between tariff data and SPS/TBT databases, we got two country pair-year-product (HS-4 digit) specific databases covering the period 1996-2010 which include all the country-product combinations having non missing info on tariff and SPS/TBT imposition. ${ }^{22}$ In the SPS (TBT) dataset we keep only those importing countries and sectors that have been object of at least one SPS (TBT) concern over the period 1996-2010. ${ }^{23}$ This is the reason why the number of observations in the SPS and TBT estimation differs. Appendix Table A1 reports the list of STCs targeted countries used in the final estimation samples.

Notice that TRAINS provides the ad valorem equivalents (AVE) of non-ad valorem tariffs (i.e. specific, compound and mixed). Thus, for those tariff lines protected by non-ad valorem measures (common practice in the agriculture sector), the effectively applied tariffs used here is the AVE of non-ad valorem tariff. Such AVE values may change over time even with constant specific rates; indeed the variation in export prices affects the AVE values even with constant non-ad valorem protection. It follows that, for some products, the time variation of the effectively applied tariff as provided by TRAINS might be biased. ${ }^{24}$ Thus, as a robustness check, in section

\footnotetext{
${ }^{21}$ TRAINS dataset also provides weighted average tariffs within HS-4 headings. But the weighting scheme, being based on bilateral trade flows, would introduce a bias in the estimations since cross year variation in weighted tariff might be due to bilateral trade flows and not by pure trade policy measures.

${ }^{22}$ For those country pair-sectors with non-missing tariff info and missing SPS/TBT, we assumed zero SPS/TBT. This seems a fairly plausible assumption. Similarly, for those country-sectors with missing tariff and non missing SPS/TBT we assumed zero tariff level.

Such selection has two motivations. First, countries/sectors that have never been targeted by STCs do not contribute to the identification of our coefficient because we use country-product-year fixed effects (for this reason a non-linear estimator would automatically drop countries/sectors never targeted by STCs). Second, STCs are "rare" events and keeping all the possible countries and sectors would end up with zero over-inflated datasets on SPS and TBT dummy.

See TRAINS methodology for more details here:
} 
4.4, we replicate the econometric exercise by using exclusively Ad Valorem Tariff provided by MacMap dataset (CEPII) ${ }^{25}$. By restricting the analysis to Ad-Valorem tariffs, we explore the pure time variation of (ad valorem) tariff protection which is not affected by AVE calculation by TRAINS.

\section{Empirical strategy}

Following the idea discussed in the introduction, this section aims to test whether Specific Trade Concerns on SPS and TBT are raised by exporting countries as a consequences of importers' tariff reductions. Indeed, an exporting country might complain at the SPS/TBT committees of the WTO when a NTM represents an effective obstacle to trade, i.e. when tariff protection reduces and the NTM is the only barrier to trade. We test this hypothesis by using the following model:

[1] $\left(S T C_{i j s t}\right)=\delta_{1}\left[\ln (\text { Tariff }+1)_{i j s t}-\ln (\text { Tariff }+1)_{i j s(t-1)}\right\rfloor+\delta_{2} \ln (\text { Tariff }+1)_{i j s(t-1)}+\delta_{3} X_{i j s t}+\theta_{i s t}+\theta_{j s t}+\varepsilon_{i j s t}$

The dependent variable $\mathrm{STC}_{\mathrm{ijst}}$ is a dummy equal to one if country pair ij has an active STC (SPS and TBT respectively) on product $s$ (HS-4 digit) at time $t$. The main explanatory variable here is the difference in the country pair-product applied tariff between time $(t)$ and $(t-1)-$ i.e. $\ln (\text { Tariff }+1)_{i j s t}-\ln (\text { Tariff }+1)_{i j s(t-1)}$. Thus $\delta_{1}$ captures the relation between tariff changes (being reductions or increases) and the presence of STC on non-tariff measure. Thus $\delta_{1}<0$ would suggest that STCs are likely to be raised by country $j$ when country $i$ reduces the applied tariff on product $s$ (for country $j$ ), this indicates that STCs are raised when the non-tariff measures become barriers to trade.

As suggested by Ray (1981), Mansfield and Busch (1995) and Moore and Zanardi (2011) the initial tariff level - before the change - affects the probability of NTMs' imposition (sectors with high initial tariffs might the ones that do not need alternative form of protection through non-tariff measures). For this reason in equation [1] we control for the lagged level of tariff $-\ln ($ Tariff + 1) $i_{i j(t-1)}$.

http://www.google.it/url?sa=t\&rct=j\&q=\&esrc=s\&source=web\&cd=2\&ved=0CCkQFjAB\&url=http\%3A\%2F\%2Fwits. worldbank. org\%2FWITS\%2Fdocs\%2FAVEmeth.doc\&ei=-dk_VPXyM87oaMSwgrgl\&usg=AFQjCNF-

1177Xx4hFhxrm2t4Z857M2aLVA\&bvm=bv.77648437,d.d2s

${ }^{25}$ MacMap dataset provides information on the nature of the tariff: ad valorem vs. non-ad valorem tariffs. See details in Guimbard et al.(2012). 
The set of control variables $X_{i j t}$ contains other important controls. As argued by Ray (1981) both tariff and non-tariff measures might be used to protect industries in which the country has comparative disadvantage. For this reason, the set of control variables $X_{i j s t}$ includes the share of HS-4 imports of country $i$ coming from country $j$ at time $t-1$ (i.e. lagged country-sector specific import penetration $)^{26}$ - it is meant as a proxy for the comparative disadvantage of country $i$ in product $s$ with respect to country $j{ }^{27}$ The set of control variables also includes country pair specific variables usually used in gravity model for trade: (i) distance, since non-tariff measures imposed by remote countries might not be of sufficient interest for raising a concern; (ii) the sum of GDPs of countries $i$ and $j$ (in log) - GDPSUM, since countries with a big mass of GDP are expected to trade more each other (standard gravity model for trade) and the imposition of a measure in this case is more important and likely gives rise to a bilateral Specific Trade Concern.

Country-product-year fixed effects $\left(\theta_{i s t}\right.$ and $\left.\theta_{j s t}\right)$ control for any country-product-year specific characteristics affecting both the probability of NTM imposition and the applied tariff level. They control for country specific macroeconomic dynamics (such as GDP growth, inflation, real effective exchange rate) and for product specific characteristics, indeed, it might be the case that NTMs are more likely to be imposed on certain types of products (because of their dangerousness for human or plant health). The omission of product specific fixed effects would bias the estimated coefficients (omitted variable bias). More importantly, the set of fixed effect we include in equation [1] properly control for country-product-year specific demand or productivity shocks that might influence the country's imposition of a tariff/non-tariff measure. Indeed, a negative productivity or demand shock in a country-product might induce the country to further protect domestic producers in the sector by increasing tariff protection or imposing a NTM. Alternatively, a negative productivity shock might induce the country to complain about a pre-existing measure simply because now its domestic producers are less competitive and the measure becomes particularly export-constraining.

The inclusion of country-product-year specific fixed effects controls also for the factor content hypotheses in NTMs formation (highlighted by Bandyopadhyay and Roy 2011). All things equal,

\footnotetext{
26

Import Penetration $_{i j s t}=\frac{\text { Import }_{i j s t}}{\sum_{j} \text { Import }_{i s j t}}$

${ }^{27}$ We take the lagged value of import penetration to avoid reverse causality problem with this control variable.
} 
labor-abundant countries are less likely to protect from trade: protectionism causes labor to lose in labor-abundant countries (Stolper Samuelson theorem), and thus the majority voting will be against trade protection (Bandyopadhyay and Roy 2011). Country-product-year fixed effects also control for the ideology hypothesis: it might be the case that the political orientation of the country affects the propensity to protect from trade by using tariffs or NTMs (Bandyopadhyay and Roy 2011). Also the size effect is captured by country-product-year fixed effects: import intensive countries and/or rich countries have been found to be positively correlated with NTMs imposition (Mansfield and Busch 1995).

All in all, the inclusion of country-product-year specific fixed effects strongly reduces any endogeneity concern due to the omitted variable problem. However, some concerns on reverse causality may remain if one imagines non-tariff measures (and then concerns) affecting tariff change over time. We dedicate section 4.3 to address the reverse causality issue by using an alternative specification to equation [1] and an Instrumental Variable approach.

Despite the dichotomous nature of the dependent variable we use a linear probability model (LPM) to estimate equation [1]. We rely on simple linear probability models (LPM) rather than on nonlinear probit (or logit) to avoid the incidental parameter problem due to the sizeable set of fixed effects we include in all regressions. In addition, LPMs provide simple direct estimates of the sample average marginal effect. It might also be the case that some SPS measures are imposed in manufacturing products, as well as TBT measures imposed in agriculture products. Such circumstances might be considered as "outliers", since typically SPS and TBT are imposed respectively in agriculture and manufacturing products, so equation [1] is also estimated on agriculture only for SPS and on manufacturing only for TBT. We finally use a subsample of years 2000-2010 as a further robustness check.

\section{Results}

In Tables 2 and 3 we report the baseline regression results of equation [1] estimated on different samples of sectors and time periods: (i) in columns 1 and 2 we show results using the full sample of sectors and years, (ii) in columns 3 and 4 we show results on sub-sample of agriculture and manufacturing sectors for the period 1996-2010 (preferred estimations), (iii) in columns 5 and 6 we show robustness checks using agriculture and manufacturing sectors for the sub-period 2000-2010. 
All in all, it emerges a clear negative correlation between changes in the tariff level and the probability of having a STC on SPS (columns 1 to 6 in Table 3): SPS concerns are raised against importer-product combinations that experienced tariff reductions. In particular, a 10\% larger tariff reduction ${ }^{28}$ implies a $0.18 \%$ higher probability a having a STC on SPS. Table 3 reports the baseline regression results for TBT imposition, which confirm the idea that, also for TBT, STCs on non-tariff barriers are raised against country-product that experienced tariff reduction: specifications in columns 1 to 6 show negative and significant coefficients for tariff change. Using our preferred specification in column (4), a 10\% larger reduction in the applied tariff implies $0.36 \%$ higher probability of having active TBT concern.

Both in SPS and TBT estimations we obtain negative and significant coefficients for the lagged bilateral tariff, this means that STCs are raised by exporting countries on products with low past tariff protection. This confirms results in Ray (1981), Mansfield and Busch (1995) and Moore and Zanardi (2011) according to which the initial tariff level affects the probability of future NTM imposition (and thus STC): sectors with high initial tariffs are the ones that do not need alternative form of protection (non-tariff measures), and so in these sectors the probability of SPS or TBT concern is low. Import penetration has also negative and significant coefficient, suggesting that exporting country raises concerns on SPS/TBT when the importing country is a relevant destination markets for its exports.

As discussed in the introduction, the STC data does not directly allow disentangling between new and pre-existing NTMs. Thus two alternative channels can explain the negative coefficients on tariff reduction in tables 2 and 3 :

i. STCs raised on pre-existing measures only after tariff reduction. In sectors with high initial tariff protection, NTMs become barriers to trade only after tariff reduction.

ii. STCs raised on new NTM. In sector with low initial tariff protection, a further tariff reduction can push the government towards the imposition of a NTM which represents immediately a barrier to trade.

We can indirectly isolate the two channels by interacting the tariff change $\ln (\operatorname{Tariff}+1)_{i j s t}$ $\ln (\text { Tariff }+1)_{i j s(t-1)}$ with the initial tariff level $\ln (\text { Tariff }+1)_{i j s(t-1)}$. If the negative effect of tariff variation

${ }^{28}$ Notice that the main explanatory variable is in first difference, so in quantifying the coefficient of tariff change one has to compare two different extends of tariff change (i.e. one the $10 \%$ larger than the other). 
is magnified for high initial tariff protection, then channel (i) plays a major role. Results in table 4 show negative and significant interaction term, meaning that the higher the initial tariff protection, the higher the probability of raising a STC after tariff reduction. This is particularly true for SPS where tariff reduction increase the probability of raising a concern only for high initial tariff level. In appendix table $A 4$, as a robustness check, we simply replicate equation [1] on those country pair-sector combinations with (lagged) tariff above the mean. This is an alternative way to isolate channel (i). Results in table A4 show that also for the sub-sample of country pair-sectors with high initial tariff protection, coefficients on tariff change remain negative and significant and similar to those in Table 2 and 3. This confirms again the major role of channel (i).

By combining results in Table 2, 3 and 4 one may argue that SPS and TBT imposition react in the same way to tariff changes over time, i.e. SPS and TBT concerns are raised in those sectors experienced recent tariff reductions. However, SPS and TBT concerns may react differently to tariff reduction depending on the primary subject of the concern and on the degree of development of raising and imposing country. The following sections explore further these channels by looking at the heterogeneity in the type of measures (human and plant health, quality requirements, etc) and at any specific pattern in SPS/TBT imposition across different income levels of countries.

\subsection{Extension : results by type of measure}

The STCs dataset provides information on the primary object of the concern at the SPS and TBT committees of the WTO. Hence this section replicates the previous evidence by type of measure. To the sake of simplicity, only four types of measures (for both SPS and TBT) have been selected here based on how frequently each type appears within the STCs list. ${ }^{29}$ For SPS measures we use the following types of measures: human and animal health, food safety, plant health and standards and harmonization measures. While for TBT we use: human health, consumer information and labeling, protection of the environment and quality requirements. Results are showed in Table 5.

It emerges that only SPS concerns on human/animal health are raised as a consequence of tariff reduction (column 1), while SPS concerns on plant health, food safety or standards harmonization are uncorrelated with recent changes in the bilateral tariff change (columns 2-4).

In practice, all the types (for SPS and TBT) have been listed, and the four most used subjects been selected. 
Interestingly, human/animal health, plant health and standards harmonization SPS concerns are raised on sectors with low past tariff protection (confirming again the existing literature, i.e. Ray 1981; Mansfield and Busch 1995; and Moore and Zanardi 2011). For all the four types of SPS concerns, we got negative and significant coefficient on import penetration (this is coherent with the evidence showed in the previous section). TBT concerns on human health and environment protection are likely to be raised as a consequence of tariff reduction, while TBT concerns on consumer info and quality requirement are uncorrelated with tariff reductions. However, all the four types of TBT concerns are raised on sectors with low past tariff protection.

This evidence reveals which types of SPS/TBT concerns are more likely to be raised as concerns at the WTO as a consequence of tariff reductions; this indirectly reveals which types of SPS/TBT are more likely to represent a barrier to trade for the potential exporting country. So we can conclude that concerns on human/animal health (being raised at SPS or TBT committee) and TBT concerns on environmental protection on are those that hamper most exports and represent a consistent barrier to trade for exporter countries.

\subsection{Extension : results by income classification of raising and imposing country ${ }^{30}$}

This section explores whether the relationship between tariff cuts and STCs differs across country pairs with different income levels. To this end the equation [1] has been augmented by including an interacted variable between the tariff change and the income group of both raising and imposing country. We define as "North" high and upper middle income countries (as defined by the World Bank), and "South" countries belonging to the low and middle low income group as defined by the World Bank. Then, we characterize every country pair as "North-North", "NorthSouth", "South-North" and "South-South" depending on the income level of the raising and imposing country respectively. Results are reported in Tables 6 and 7 .

Tariff change continues to be on average negatively related with SPS and TBT concerns (see first row in columns 1-4 of tables 6 and 7), in line with results showed in Tables 2 and 3 . However, the type of country-pair matters for TBT concerns only (for SPS concerns the interacted variables are never significant). Namely, the negative relationship between TBT concerns and tariff change is magnified when the raising and the imposing country belong to the same income group ("North-North" or "South-South") - see columns 1 and 2 in table 7. A 10\%

${ }^{30}$ Raising country is the country complaining against a measure at the SPS/TBT committee of the WTO. The imposing country is the country that imposed the NTM and is targeted by the Specific Trade Concern. 
larger tariff reduction for a homogeneous country pair ("North-North") corresponds to a $0.5 \%$ higher probability of TBT concern (it corresponds to $0.8 \%$ for a "South-South" country pairs).

This evidence is coherent with the idea that TBTs represent an obstacle to trade when the raising (exporter) and the maintaining country (importer) compete on a similar quality level for a given product HS4 (the underlying assumption here is that rich country realize high quality product with respect low income countries). Conversely, the degree of substitutability between tariff and TBT concerns reduces (becoming almost null) for heterogeneous country pairs ("NorthSouth" or "South-North") - see columns 3 and 4. This is in line with the fact that TBTs do not represent an obstacle to trade when the exporter (raising) and the importer (maintaining) country compete on product with different quality levels.

As a robustness check of this idea, in Table 8 we interact the tariff change variable with the absolute difference in (export) Trade Unit Values between raising and maintaining country: ${ }^{31}$

$$
\text { Abs Differencein } T U V_{i j s, 1995}=\left|T U V_{j s, 1995}-T U V_{i s, 1995}\right|
$$

The absolute difference in TUV reflects the quality difference between country $j$ and $i$ in producing (and then selling abroad) the product $s$. High difference in TUV suggests different quality levels between country $j$ and $i$ in producing $s$. Results in Table 8 show that, after tariff reduction, TBTs become stronger obstacles to trade when raising and imposing country have similar quality level (positive interaction term): a tariff reduction implies higher probability of TBT concern when the absolute difference in TUV reduces (similar quality). Conversely, when the quality difference between imposing and raising country gets wider, the negative relation between tariff change and active TBT concerns is attenuated.

\subsection{Endogeneity}

The inclusion of country-product-year fixed effects drastically reduces the omitted variable problem, indeed, most of the unobservable factors affecting both NTMs imposition and tariff changes are captured by fixed effects. However, endogeneity concern might rise from reverse causality problem: the imposition of a new NTM (underlying the STC) might push the importing country to reduce the import tariff applied to a specific exporter. Indentifying pure random

\footnotetext{
${ }^{31}$ To reduce any concern of endogeneity TUVs for imposing and raisin countries have been taken as of 1995.
} 
variation in tariff protection is extremely hard and it is still an open discussion in the existing literature. So here we address the reverse causality problem in two steps. First, we estimate equation [1] by using lagged tariff change $\left(\operatorname{In}(\text { Tariff }+1)_{i j s t-1}-\operatorname{In}(\text { Tariff }+1)_{i j s(t-2)}\right)$ - as already done in Beverelli et al. (2014). The further time lag reduces reverse causality concern (the fact that a concern is raised at time $t$ means that the underlying non-tariff measure is imposed or became trade hampering at time $t$ and hardly affects tariff change between time $(t-2)$ and $(t-1))$. Results for this first robustness check are reported in table 9 and fully confirm what we discussed in the previous sections: negative and significant coefficient for tariff change on both SPS and TBT concerns.

Then we also use an Instrumental Variable approach to further reduce concerns of reverse causality. Our instrument is the imputed bilateral applied tariff change, where the imputed applied tariff level has been computed as the product between: (i) the average importer-product specific tariff level (average across partner countries within product-importing country); and (ii) the average country pair tariff level (average across products within country pair):

$$
\text { Imputed Tariff }_{i j s t}=\left(\frac{1}{J} \sum_{j} \tau_{i j s t}\right) *\left(\frac{1}{S} \sum_{s} \tau_{i j s t}\right)
$$

The instrument described above is positively correlated with the country pair-product specific tariff level suggesting the relevance of the instrumental variable in explaining the (potential) endogenous variable. First stage results of our 2SLS strategy are reported at the bottom of Table 10, first stage coefficients always positive and statistically significant. However, the inclusion of huge sets of fixed effect (country-product-year in this case) might reduce the power of the instrument (weak instrument). For this reason, in 2SLS estimations we reduce the amount of fixed effects. Instead of using country-product-year we use county-sector HS2-year fixed effects. Results reported in table 10 show the relevance of the instrument (imputed tariff change positively correlated with the observed tariff change) and F-statistics above 10 (rule of thumbs for avoiding weak instrument problem). ${ }^{32}$

The exclusion restriction (or validity) of our instrumental variable is related to the fact that the tariff applied by country $i$ on product $s$ towards all its trade partners (all $j$ countries in $J$ ) is likely expected, the F-statistics reduces below 10 suggesting weak instrument problem. But the relevance of the instrument remains quite high (see first stage coefficients).
} 
unrelated with the presence of a STC raised by a specific country $j$ (exclusion restriction for the first term in equation [3]). Similarly, the tariff applied by $i$ towards $j$ on all the products they trade each other does not depend on the presence on a STC on specific product $s$ (exclusion restriction for the second term in equation [3]). Results on 2SLS estimations are reported in tables 10 (and A5) and confirm the main results we described so far: for both SPS and TBT concerns we find negative and significant coefficient for tariff change, suggesting again that exporting country raises a concern on SPS or TBT after a tariff reduction by the importing countries.

\subsection{Robustness using MacMap}

As already mentioned in the data section, the effectively applied tariff provided by TRAINS might have a biased time variation since the AVE values reported for non-ad valorem protection change with the dynamics of export prices. To solve this problem, as a robustness check, we use only ad valorem tariff protection by excluding from the dataset: (i) specific tariffs and (ii) compound tariffs. This is doable with MacMap database (CEPII) that provides detailed information on the kind of protection. We can thus isolate the pure ad-valorem tariff and estimating equation [1] using only this kind of protection. ${ }^{33}$

Unfortunately, MacMap tariff dataset reflects the status of applied tariff in 2001, 2004, 2007 and 2010. This means that applied tariff changes occurred between two consecutive years of data collection are recorded in the year of next data collection (for example, tariff variations occurred in 2008, i.e. between data collections in 2007 and 2010, are recorded in 2010). For this reason we used lagged tariff change $\left.\left(\operatorname{In}(\text { Tariff }+1)_{i j s t-1}-\operatorname{In}(\text { Tariff }+1)_{i j s(t-2)}\right)\right)$ - as already described in section 4.3. This makes sure we consider the effect of previous tariff change on current SPS/TBT concerns. Given the nature of MacMap dataset, we accordingly use a repeated cross section approach (as a difference with the pure panel data approach used in previous section), and the dependent variable is now a dummy equal to one if an active SPS/TBT concerns is raised between two subsequent years of data collection. ${ }^{34}$ The set of fixed effects and control variables remain unchanged. Results, reported in Table 11, confirm what found so far: both SPS

\footnotetext{
33

In this way we lose all sectors being protected exclusively by non-ad valorem tariff. This is the reason why the number of observations in Table 10 reduces with respect to Table 2 and 3 . The second reason for the reduced number of observations is the lag structure of the estimations (tariff change has been computed as (t-2)-(t-1)).

Namely dummy equal to one if a concern is raised between: (i) 2001 and 2004, (ii) 2004 and 2007 and (iii) 2007 and 2010. In this case the resolution of a STC corresponds to an absence of STC (dummy equal to zero).
} 
and TBT concerns are raised after reductions in (ad valorem) tariff protection. This robustness check is particularly relevant for SPS in agriculture sector, where non-ad valorem tariff protection is often used and AVE by TRAINS might provide biased results in Table 2.

\section{Conclusion}

The findings of this paper support the worry expressed by Pascal Lamy in its farewell statement to the General Council of the WTO: NTMs can represent an effective barrier to trade. Indeed, when NTMs become trade barriers (i.e. after tariff liberalization) exporting countries raise Specific Trade Concerns at the dedicated committees at the WTO. Indeed, we find that STCs (on SPS and TBT) are raised by exporting countries when the underlying NTM becomes a barrier to trade, i.e. when tariff protection reduces in a given country-product. According to our preferred estimation, tariff cut implying a $10 \%$ lower tariff-inclusive price corresponds to a $0.18 \%$ and $0.36 \%$ higher probability of observing a STC on SPS and TBT respectively. This figure grows up to $0.5 \%-0.8 \%$ when both raising and imposing country belong to the same income group. This suggests that TBTs represent an obstacle to trade when the exporter and the importer country compete on product with similar quality level. We also find that concerns having human/animal health or environmental protection as primary objective are those that show strong negative coefficient on tariff change. This means that human/animal health or environmental protection, after tariff liberalization, hamper most exports and represent a consistent barrier to trade for exporter countries. 


\section{Tables and Figure}

Figure 1 - SPS concerns and applied tariff level. 1996-2010.

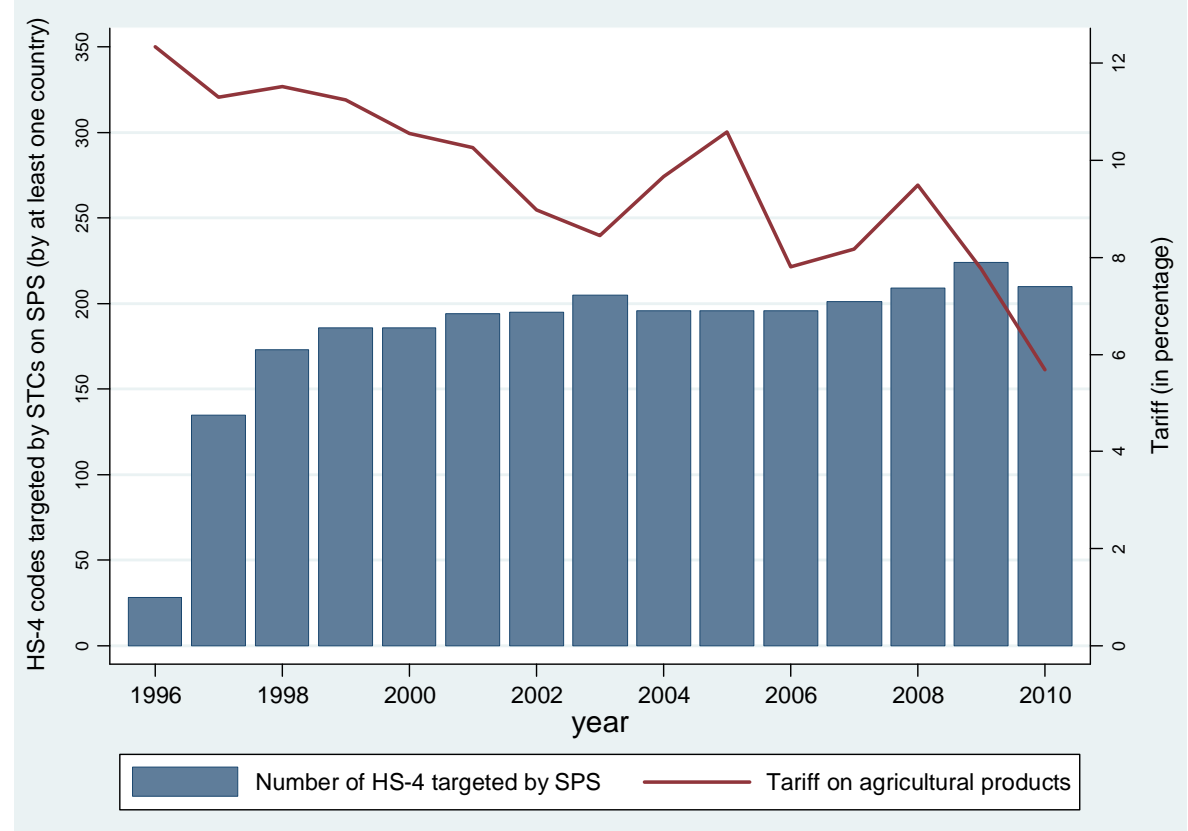

Source: WTO, STC dataset and TRAINS.

Figure 2 - TBT concerns and applied tariff level. 1996-2010.

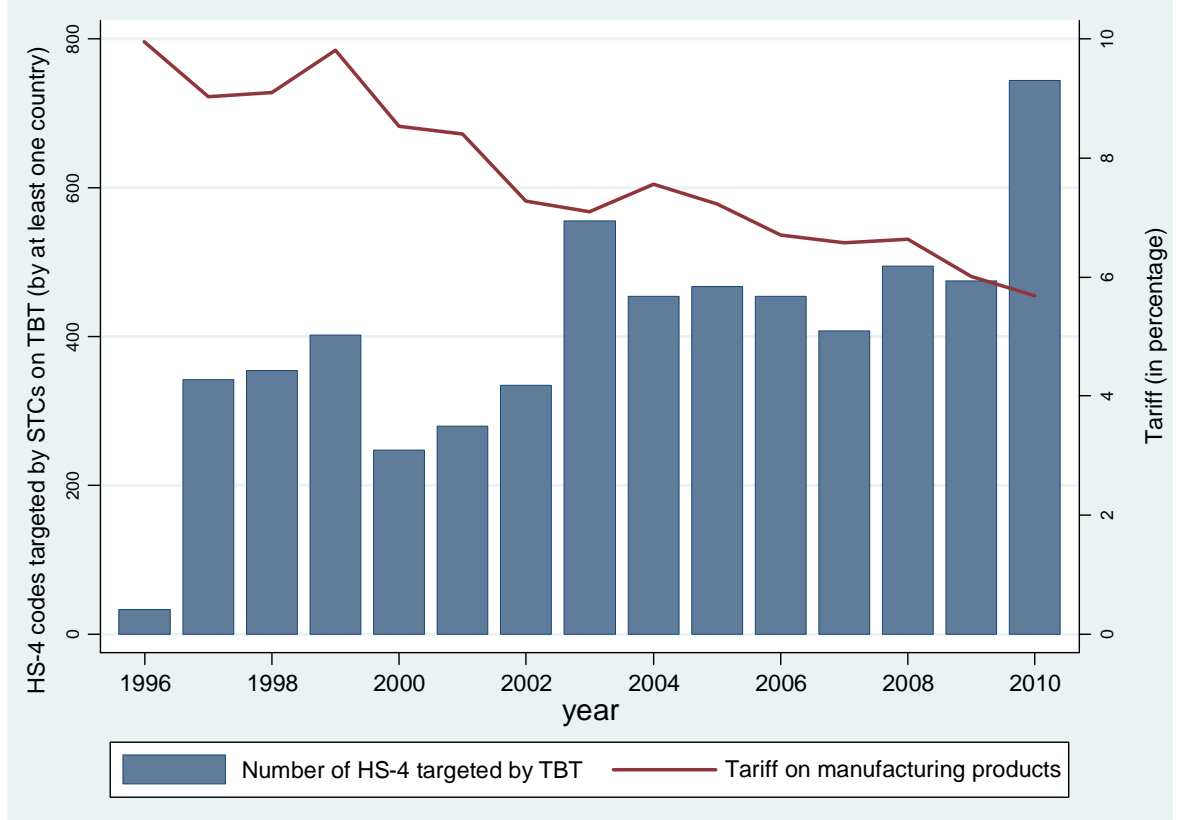

Source: WTO, STC dataset and TRAINS. 
Table 1 - SPS and TBT concerns (2000, 2005 and 2010).

\begin{tabular}{|c|c|c|c|}
\hline & 2000 & 2005 & 2010 \\
\hline N. of countries targeted by at least one SPS concern & 29 & 48 & 57 \\
\hline of which developing countries & 24 & 42 & 51 \\
\hline of which developed countries & 5 & 6 & 6 \\
\hline N. of countries targeted by at least one TBT concern & 6 & 13 & 19 \\
\hline of which developing countries & 2 & 10 & 16 \\
\hline of which developed countries & 4 & 3 & 3 \\
\hline N. of HS-4 under SPS concerns in at least one country & 186 & 196 & 210 \\
\hline of which developing countries & 50 & 17 & 8 \\
\hline of which developed countries & 136 & 179 & 202 \\
\hline N. of HS-4 under TBT concerns in at least one country & 247 & 467 & 744 \\
\hline of which developing countries & 3 & 188 & 188 \\
\hline of which developed countries & 244 & 279 & 556 \\
\hline Applied Tariff (average) ${ }^{a}$ & 6.95 & 5.38 & 4.65 \\
\hline By developing countries & 10.01 & 7.19 & 5.77 \\
\hline By developed countries & 4.43 & 3.74 & 3.48 \\
\hline
\end{tabular}

Note: the WTO definition of Developed vs Developing countries has been used. ${ }^{a}$ World tariff protection calculated as simple average across countries. Source: Author's calculation on WTO, STCs database and TRAINS World Bank. 
Table 2 - SPS Baseline regression results.

\begin{tabular}{|c|c|c|c|c|c|c|}
\hline \multirow[t]{2}{*}{ Dependent variable: } & \multicolumn{6}{|c|}{ Dummy if active STC on SPS } \\
\hline & (1) & (2) & (3) & (4) & (5) & (6) \\
\hline \multirow[t]{2}{*}[\operatorname{ln}(\text{tariff}_{\mathrm{t}})-\operatorname{ln}(\text{tariff}_{\mathrm{t}-1})]{} & $-0.012^{\star \star}$ & $-0.013^{\star * \star}$ & $-0.017^{\star \star \star}$ & $-0.018^{\star \star \star}$ & $-0.014^{\star \star}$ & $-0.014^{\star \star}$ \\
\hline & $(0.005)$ & $(0.005)$ & $(0.005)$ & $(0.005)$ & $(0.006)$ & $(0.006)$ \\
\hline \multirow[t]{2}{*}{$\operatorname{Ln}\left(\right.$ tariff $\left._{t-1}\right)$} & $-0.044^{\star \star *}$ & $-0.046^{\star \star \star}$ & $-0.056^{\star \star *}$ & $-0.057^{\star \star \star}$ & 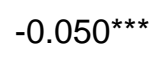 & $-0.051^{\star \star *}$ \\
\hline & $(0.004)$ & $(0.004)$ & $(0.00487)$ & $(0.00487)$ & $(0.005)$ & $(0.005)$ \\
\hline \multirow[t]{2}{*}{ Import Penetration $_{\mathrm{t}-1}$} & & $-0.014^{\star \star \star}$ & & $-0.013^{\star \star \star}$ & & $-0.013^{\star * \star}$ \\
\hline & & $(0.001)$ & & $(0.001)$ & & $(0.001)$ \\
\hline Sample & \multicolumn{2}{|c|}{ Full sample } & \multicolumn{2}{|c|}{ Agriculture } & \multicolumn{2}{|c|}{ Agriculture 2000-2010 } \\
\hline Exporter-Product-Year FE & yes & yes & yes & yes & yes & yes \\
\hline Importer-Product-Year FE & yes & yes & yes & yes & yes & yes \\
\hline Country Pair controls & yes & yes & yes & yes & yes & yes \\
\hline Observations & 685,091 & 685,091 & 384,699 & 384,699 & 323,520 & 323,520 \\
\hline R-sq & 0.762 & 0.762 & 0.843 & 0.843 & 0.845 & 0.845 \\
\hline
\end{tabular}

Note: Robust standard error in parentheses. Country pair specific controls are distance and GDPSUM.*, ${ }^{\star \star},{ }^{\star \star \star}$ indicate significance at the 10, 5 and $1 \%$ confidence level. 
Table 3 - TBT Baseline regression results.

\begin{tabular}{|c|c|c|c|c|c|c|}
\hline \multirow[t]{2}{*}{ Dependent variable: } & \multicolumn{6}{|c|}{ Dummy if active STC on TBT } \\
\hline & (1) & (2) & (3) & (4) & (5) & (6) \\
\hline \multirow[t]{2}{*}[\operatorname{ln}(\text{tariff}_{t})-\operatorname{ln}(\text{tariff}_{\mathrm{t}-1})]{} & $-0.026^{\star \star \star}$ & $-0.026^{\star \star *}$ & $-0.035^{\star \star \star}$ & $-0.036^{\star \star *}$ & $-0.036^{\star \star \star}$ & $-0.036^{\star \star \star}$ \\
\hline & $(0.002)$ & $(0.002)$ & $(0.003)$ & $(0.003)$ & $(0.003)$ & $(0.003)$ \\
\hline $\operatorname{Ln}\left(\right.$ tariff $\left._{\mathrm{t}-1}\right)$ & $(0.002)$ & $(0.002)$ & $(0.003)$ & $(0.003)$ & $(0.003)$ & $(0.003)$ \\
\hline Import Penetration $_{\mathrm{t}-1}$ & & $-0.008^{\star \star \star}$ & & $-0.005^{\star \star \star}$ & & $-0.005^{\star \star \star}$ \\
\hline Exporter-Product-Year FE & yes & yes & yes & yes & yes & yes \\
\hline Importer-Product-Year FE & yes & yes & yes & yes & yes & yes \\
\hline Country Pair controls & yes & yes & yes & yes & yes & yes \\
\hline Observations & $3,360,117$ & $3,360,117$ & $2,956,725$ & $2,956,725$ & $2,486,045$ & $2,486,045$ \\
\hline R-sq & 0.691 & 0.691 & 0.685 & 0.685 & 0.689 & 0.689 \\
\hline
\end{tabular}

Note: Robust standard error in parentheses. Country pair specific controls are distance and GDPSUM. *, **, *** indicate significance at the 10, 5 and $1 \%$ confidence level 


\begin{tabular}{|c|c|c|c|c|c|c|c|c|}
\hline \multicolumn{9}{|c|}{ Table 4 - SPS and TBT concerns when (lag) tariffs are high } \\
\hline \multirow[t]{2}{*}{ Dependent variable: } & \multicolumn{4}{|c|}{ Dummy if active STC on SPS } & \multicolumn{4}{|c|}{ Dummy if active STC on TBT } \\
\hline & (1) & $(2)$ & (3) & (4) & (5) & (6) & (7) & (8) \\
\hline \multirow[t]{2}{*}{$\ln \left(\right.$ tariff $\left._{t}\right)-\ln \left(\right.$ tariff $\left.\left._{t-1}\right)\right]$} & -0.006 & -0.007 & -0.010 & $-0.011^{*}$ & $-0.019 * \star \star$ & $-0.019 * \star \star$ & $-0.033^{\star \star \star}$ & $-0.033^{\star \star \star}$ \\
\hline & $(0.005)$ & $(0.005)$ & $(0.006)$ & $(0.006)$ & $(0.003)$ & $(0.003)$ & $(0.003)$ & $(0.003)$ \\
\hline \multirow[t]{2}{*}[\operatorname{ln}(\operatorname{tariff}t)-\operatorname{ln}(\operatorname{tariff}_{\mathrm{t}-1})]{$^{\star} \mathrm{Ln}\left(\operatorname{tariff}_{\mathrm{t}-1}\right)$} & $-0.012^{\star \star}$ & $-0.011^{\star *}$ & $-0.015^{\star}$ & $-0.015^{\star}$ & $-0.023^{\star * *}$ & $-0.023^{\star \star *}$ & $-0.013^{*}$ & $-0.013^{\star}$ \\
\hline & $(0.006)$ & $(0.006)$ & $(0.007)$ & $(0.007)$ & $(0.004)$ & $(0.004)$ & $(0.007)$ & $(0.007)$ \\
\hline \multirow[t]{2}{*}{$\operatorname{Ln}\left(\operatorname{tariff}_{\mathrm{t}-1}\right)$} & $-0.044^{\star \star \star}$ & $-0.045^{\star \star \star}$ & $-0.056^{\star \star \star}$ & $-0.057^{\star \star \star}$ & $-0.069^{\star \star \star}$ & $-0.070^{\star \star *}$ & $-0.094^{\star \star \star}$ & $-0.096^{\star \star \star}$ \\
\hline & $(0.004)$ & $(0.004)$ & $(0.005)$ & $(0.005)$ & $(0.002)$ & $(0.002)$ & $(0.003)$ & $(0.003)$ \\
\hline Import Penetration & & $(0.001)$ & & $(0.001)$ & \multicolumn{3}{|c|}{$(0.001)$} & $(0.001)$ \\
\hline Sample & \multicolumn{2}{|c|}{ Full sample } & \multicolumn{2}{|c|}{ Agriculture } & \multicolumn{2}{|c|}{ Full sample } & \multicolumn{2}{|c|}{ Manufacturing } \\
\hline Exporter-Product-Year FE & yes & yes & yes & yes & yes & yes & yes & yes \\
\hline Importer-Product-Year FE & yes & yes & yes & yes & yes & yes & yes & yes \\
\hline Country Pair controls & yes & yes & yes & yes & yes & yes & yes & yes \\
\hline Observations & 685,091 & 685,091 & 384,699 & 384,699 & $3,360,117$ & $3,360,117$ & $2,956,725$ & $2,956,725$ \\
\hline R-sq & 0.762 & 0.762 & 0.843 & 0.843 & 0.691 & 0.691 & 0.685 & 0.685 \\
\hline
\end{tabular}

Note: Robust standard error in parentheses. Country pair specific controls are distance and GDPSUM.* ${ }^{\star \star},{ }^{\star \star \star}$ indicate significance at the 10,5 and $1 \%$ confidence level. 


\begin{tabular}{|c|c|c|c|c|c|c|c|c|}
\hline \multicolumn{9}{|c|}{ Table 5 - SPS and TBT concerns by type of measure } \\
\hline Dependent variable: & \multicolumn{4}{|c|}{ Dummy if active STC on SPS } & \multicolumn{4}{|c|}{ Dummy if active STC on TBT } \\
\hline Type of measure & $\begin{array}{l}\text { Human and } \\
\text { Animal health }\end{array}$ & Food safety & Plant health & $\begin{array}{c}\text { Standards } \\
\text { harmonization }\end{array}$ & Human health & $\begin{array}{c}\text { Consumer } \\
\text { Info, labelling }\end{array}$ & $\begin{array}{l}\text { Protection of } \\
\text { environment }\end{array}$ & $\begin{array}{l}\text { Quality } \\
\text { requirements }\end{array}$ \\
\hline & (1) & (2) & (3) & (4) & (5) & (6) & (7) & (8) \\
\hline \multirow[t]{2}{*}[\operatorname{ln}(\text{tariff}_{t})-\operatorname{ln}(\text{tariff}_{\mathrm{t}-1})]{} & $-0.016^{\star \star \star}$ & -0.000 & -0.002 & -0.002 & $-0.038^{\star \star \star}$ & 0.000 & $-0.034^{\star \star \star}$ & 0.001 \\
\hline & $(0.005)$ & $(0.002)$ & $(0.005)$ & $(0.004)$ & $(0.003)$ & $(0.001)$ & $(0.003)$ & $(0.000)$ \\
\hline \multirow[t]{2}{*}{$\operatorname{Ln}\left(\right.$ tariff $\left._{\mathrm{t}-1}\right)$} & $-0.046^{\star \star \star}$ & -0.002 & $-0.025^{\star \star \star}$ & $-0.006^{*}$ & $-0.093^{\star \star \star}$ & $0.002^{\star \star \star}$ & $-0.091^{\star \star \star}$ & $0.001^{\star \star}$ \\
\hline & $(0.005)$ & $(0.002)$ & $(0.004)$ & $(0.003)$ & $(0.003)$ & $(0.001)$ & $(0.003)$ & $(0.000)$ \\
\hline \multirow[t]{2}{*}{ Import Penetration $_{\mathrm{t}-1}$} & $-0.008^{\star \star \star}$ & $-0.004^{\star \star \star}$ & $-0.008^{\star \star \star}$ & $-0.002^{*}$ & $-0.003^{\star \star \star}$ & $-0.001^{\star \star \star}$ & $-0.003^{\star \star \star}$ & $-0.002^{\star \star \star}$ \\
\hline & $(0.001)$ & $(0.000)$ & $(0.001)$ & $(0.001)$ & $(0.001)$ & $(0.000)$ & $(0.001)$ & $(0.000)$ \\
\hline Sample & \multicolumn{4}{|c|}{ Agriculture } & \multicolumn{4}{|c|}{ Manufacturing } \\
\hline Exporter-Product-Year FE & yes & yes & yes & yes & yes & yes & yes & yes \\
\hline Importer-Product-Year FE & yes & yes & yes & yes & yes & yes & yes & yes \\
\hline Country Pair controls & yes & yes & yes & yes & yes & yes & yes & yes \\
\hline Observations & 384,699 & 384,699 & 384,699 & 384,699 & $2,956,725$ & $2,956,725$ & $2,956,725$ & $2,956,725$ \\
\hline R-sq & 0.803 & 0.920 & 0.776 & 0.819 & 0.700 & 0.311 & 0.704 & 0.198 \\
\hline
\end{tabular}

Note: Robust standard error in parentheses. Country pair specific controls are distance and GDPSUM.*, ${ }^{\star \star},{ }^{\star \star \star}$ indicate significance at the 10,5 and $1 \%$ confidence level. 
Table 6 - SPS concerns by region. Agriculture only.

\begin{tabular}{|c|c|c|c|c|}
\hline \multirow[t]{2}{*}{ Dependent variable: } & \multicolumn{4}{|c|}{ Dummy if active STC on SPS } \\
\hline & (1) & (2) & (3) & (4) \\
\hline \multirow{2}{*}[\operatorname{ln}(\operatorname{tariff}t)-\operatorname{ln}(\operatorname{tariff}t-1)]{} & $-0.018^{\star \star \star}$ & $-0.016^{\star \star \star}$ & $-0.019 * \star \star$ & $-0.021^{\star \star \star}$ \\
\hline & $(0.007)$ & $(0.006)$ & $(0.006)$ & $(0.006)$ \\
\hline \multirow{2}{*}[\operatorname{ln}(\operatorname{tariff}f_{t})-\operatorname{ln}(\text{tariff}_{\mathrm{t}-1})]{$^{\star}$ North-North } & -0.001 & & & \\
\hline & $(0.009)$ & & & \\
\hline \multirow[t]{2}{*}[\operatorname{ln}(\operatorname{tariff}f_{t})-\operatorname{ln}(\text{tariff}_{\mathrm{t}-1})]{$^{\star}$ South-South } & & -0.015 & & \\
\hline & & $(0.011)$ & & \\
\hline \multirow{2}{*}[\operatorname{ln}(\text{tariff}f_{t})-\operatorname{ln}(\text{tariff}f_{-1})]{$^{\star}$ North-South } & & & 0.002 & \\
\hline & & & $(0.012)$ & \\
\hline \multirow[t]{2}{*}[\operatorname{ln}(\operatorname{tariff}t_{t})-\operatorname{ln}(\operatorname{tariff}_{\mathrm{t}-1})]{$^{\star}$ South-North } & & & & 0.012 \\
\hline & & & & $(0.010)$ \\
\hline \multirow[t]{2}{*}{$\operatorname{Ln}\left(\right.$ tariff $\left._{\mathrm{t}-1}\right)$} & $-0.056^{\star \star \star}$ & $-0.056^{\star \star \star}$ & $-0.056^{\star \star \star}$ & $-0.056^{\star \star \star}$ \\
\hline & $(0.005)$ & $(0.005)$ & $(0.005)$ & $(0.005)$ \\
\hline \multirow[t]{2}{*}{ Import Penetration $_{\mathrm{t}-1}$} & $-0.018^{\star \star \star}$ & $-0.018^{\star \star \star}$ & $-0.018^{\star \star \star}$ & $-0.018^{\star \star \star}$ \\
\hline & $(0.001)$ & $(0.001)$ & $(0.001)$ & $(0.001)$ \\
\hline Exporter-Product-Year FE & yes & yes & yes & yes \\
\hline Importer-Product-Year FE & yes & yes & yes & yes \\
\hline Country Pair controls & yes & yes & yes & yes \\
\hline Observations & 384,699 & 384,699 & 384,699 & 384,699 \\
\hline R-sq & 0.844 & 0.844 & 0.844 & 0.844 \\
\hline
\end{tabular}

Note: North-North, South-South, South-North and North-South dummies always included but not reported. Country Pair controls are distance and GDPSUM. Robust standard error in parentheses. .*, **, *** indicate significance at the 10,5 and $1 \%$ confidence level 
Table 7 - TBT concerns by region. Manufacturing only.

\begin{tabular}{|c|c|c|c|c|}
\hline \multirow[t]{2}{*}{ Dependent variable: } & \multicolumn{4}{|c|}{ Dummy if active STC on TBT } \\
\hline & (1) & (2) & (3) & (4) \\
\hline \multirow[t]{2}{*}[\operatorname{ln}(\text{tariff})-\operatorname{ln}(\text{tariff}_{\mathrm{t}-1})]{} & $-0.021^{* \star *}$ & $-0.032^{* * *}$ & $-0.039 * \star \star$ & $-0.046^{\star \star \star}$ \\
\hline & $(0.004)$ & $(0.003)$ & $(0.003)$ & $(0.003)$ \\
\hline \multirow[t]{2}{*}[\operatorname{ln}(\text{tariff}f_{t})-\operatorname{ln}(\text{tariff}_{t-1})]{$^{\star}$ North-North } & $-0.028^{\star \star \star}$ & & & \\
\hline & $(0.005)$ & & & \\
\hline \multirow[t]{2}{*}[\operatorname{ln}(\text{tariff})-\operatorname{ln}(\text{tariff}_{t-1})]{$^{\star}$ South-South } & & $-0.047^{\star \star \star}$ & & \\
\hline & & $(0.005)$ & & \\
\hline \multirow[t]{2}{*}[\operatorname{ln}(\operatorname{tariff}f_{t})-\operatorname{ln}(\text{tariff}_{t-1})]{$^{\star}$ North-South } & & & $0.016^{\star * \star}$ & \\
\hline & & & $(0.006)$ & \\
\hline \multirow[t]{2}{*}[\operatorname{ln}(\text{tariff}_{\mathrm{t}})-\operatorname{ln}(\text{tariff}_{\mathrm{t}-1})]{$^{\star}$ South-North } & & & & $0.055^{\star \star \star}$ \\
\hline & & & & $(0.005)$ \\
\hline \multirow[t]{2}{*}{$\operatorname{Ln}\left(\right.$ tariff $\left._{t-1}\right)$} & $-0.096^{\star \star \star}$ & $-0.096^{\star \star \star}$ & $-0.096^{\star \star \star}$ & $-0.095^{\star \star \star}$ \\
\hline & $(0.003)$ & $(0.003)$ & $(0.003)$ & $(0.003)$ \\
\hline \multirow[t]{2}{*}{ Import Penetration $_{\mathrm{t}-1}$} & $-0.006^{\star \star \star}$ & $-0.006^{\star \star \star}$ & $-0.006^{\star \star \star}$ & $-0.006^{\star \star \star}$ \\
\hline & $(0.001)$ & $(0.001)$ & $(0.001)$ & $(0.001)$ \\
\hline Exporter-Product-Year FE & yes & yes & yes & yes \\
\hline Importer-Product-Year FE & yes & yes & yes & yes \\
\hline Country Pair controls & yes & yes & yes & yes \\
\hline Observations & $2,956,725$ & $2,956,725$ & $2,956,725$ & $2,956,725$ \\
\hline R-sq & 0.685 & 0.685 & 0.685 & 0.685 \\
\hline
\end{tabular}

Note: North-North, South-South, South-North and North-South dummies always included but not reported. Country Pair controls are distance and GDPSUM. Robust standard error in parentheses. .*, **, *** indicate significance at the 10,5 and $1 \%$ confidence level 
Table 8 - NTM concerns and quality similarity.

\begin{tabular}{|c|c|c|c|c|}
\hline \multirow[t]{2}{*}{ Dependent variable: } & \multicolumn{2}{|c|}{ Dummy if active STC on SPS } & \multicolumn{2}{|c|}{ Dummy if active STC on TBT } \\
\hline & (1) & (2) & (3) & (4) \\
\hline \multirow[t]{2}{*}[\operatorname{ln}(\operatorname{tariff}_{\mathrm{t}})-\operatorname{ln}(\operatorname{tariff}_{\mathrm{t}-1})]{} & $-0.016^{\star \star}$ & 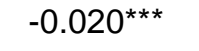 & $-0.035^{\star \star \star}$ & $-0.035^{\star \star \star}$ \\
\hline & $(0.007)$ & $(0.007)$ & $(0.004)$ & $(0.005)$ \\
\hline \multirow[t]{2}{*}[\operatorname{ln}(\text{tariff}_{t})-\operatorname{ln}(\text{tariff}_{t-1})]{$^{\star} A$ Abs Difference in TUV $(\operatorname{In})$} & 0.001 & 0.000 & $0.002^{\star \star \star}$ & 0,000 \\
\hline & $(0.001)$ & $(0.002)$ & $(0.000)$ & $(0.001)$ \\
\hline \multirow[t]{2}{*}{$\operatorname{Ln}\left(\right.$ tariff $\left._{\mathrm{t}-1}\right)$} & $-0.044^{\star \star *}$ & $-0.055^{\star \star \star}$ & $-0.067^{\star \star \star}$ & $-0.086^{\star \star \star}$ \\
\hline & $(0.004)$ & $(0.005)$ & $(0.003)$ & $(0.003)$ \\
\hline \multirow[t]{2}{*}{ Import Penetration } & $-0.015^{\star \star \star}$ & $-0.013^{\star \star \star}$ & $-0.010 * \star \star$ & $-0.007^{\star \star \star}$ \\
\hline & $(0.001)$ & $(0.001)$ & $(0.001)$ & $(0.001)$ \\
\hline \multirow[t]{2}{*}{ Abs Difference in TUV (In) } & $-0.002^{\star \star \star}$ & $-0.002^{\star \star \star}$ & $-0.001^{\star \star \star}$ & $-0.001^{\star \star \star}$ \\
\hline & $(0.000)$ & $(0.000)$ & $(0.000)$ & $(0.000)$ \\
\hline Sample & Full sample & Agriculture & Full sample & Manufacturing \\
\hline Observations & 631,379 & 349,192 & $3,124,139$ & $2,747,437$ \\
\hline R-sq & 0.757 & 0.841 & 0.655 & 0.636 \\
\hline
\end{tabular}

Note: Robust standard error in parentheses. Country-Products-Year fixed effects always included. Country pair specific controls always included are distance and GDPSUM. .*, ${ }^{\star \star}, * \star \star$ indicate significance at the 10,5 and $1 \%$ confidence level 
Table 9 - SPS/TBT concerns and lagged Tariff change.

\begin{tabular}{|c|c|c|c|c|c|c|}
\hline \multirow[t]{2}{*}{ Dependent variable: } & \multicolumn{3}{|c|}{ Dummy if active STC on SPS } & \multicolumn{3}{|c|}{ Dummy if active STC on TBT } \\
\hline & (1) & (2) & (3) & (4) & (5) & (6) \\
\hline \multirow[t]{2}{*}[\operatorname{ln}(\operatorname{tariff}_{\mathrm{t}-1})-\operatorname{ln}(\text{tariff}_{\mathrm{t}-2})]{} & $-0.016^{\star \star \star}$ & $-0.023^{\star \star \star}$ & $-0.018^{\star \star}$ & $-0.025^{\star \star \star}$ & $-0.041^{\star \star \star}$ & $-0.040^{\star \star \star}$ \\
\hline & $(0.006)$ & $(0.007)$ & $(0.008)$ & $(0.003)$ & $(0.004)$ & $(0.004)$ \\
\hline \multirow[t]{2}{*}{$\operatorname{Ln}\left(\right.$ tariff $\left._{\mathrm{t}-2}\right)$} & $-0.064^{\star \star \star}$ & $-0.077^{\star \star \star}$ & 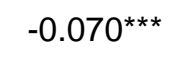 & $-0.071^{\star \star \star}$ & $-0.107^{\star \star \star}$ & $-0.111^{\star \star \star}$ \\
\hline & $(0.005)$ & $(0.006)$ & $(0.007)$ & $(0.003)$ & $(0.004)$ & $(0.004)$ \\
\hline \multirow[t]{2}{*}{ Import Penetration $_{\mathrm{t}-1}$} & $-0.015^{\star \star \star}$ & $-0.015^{\star \star \star}$ & $-0.015^{\star \star \star}$ & $-0.007^{\star \star \star}$ & $-0.004^{\star \star \star}$ & $-0.003^{\star \star \star}$ \\
\hline & $(0.001)$ & $(0.002)$ & $(0.002)$ & $(0.001)$ & $(0.001)$ & $(0.001)$ \\
\hline Sample & Full sample & Agriculture & $\begin{array}{l}\text { Agriculture } \\
2000-2010\end{array}$ & Full sample & Manufacturing & $\begin{array}{c}\text { Manufacturing } \\
2000-2010\end{array}$ \\
\hline Exporter-Product-Year FE & yes & yes & yes & yes & yes & yes \\
\hline Importer-Product-Year FE & yes & yes & yes & yes & yes & yes \\
\hline Country Pair controls & yes & yes & yes & yes & yes & yes \\
\hline Observations & 554,666 & 312,734 & 276,930 & $2,753,750$ & $2,416,568$ & $2,148,581$ \\
\hline R-sq & 0.774 & 0.850 & 0.851 & 0.720 & 0.716 & 0.717 \\
\hline
\end{tabular}

Note: Country Pair controls always included are distance and GDPSUM. Robust standard error in parentheses .*, **, ${ }^{* * *}$ indicate significance at the 10,5 and $1 \%$ confidence level 
Table 10. SPS and TBT concerns. Instrumental Variable regressions.

\begin{tabular}{|c|c|c|c|c|}
\hline \multirow[t]{2}{*}{ Dependent variable: } & \multicolumn{2}{|c|}{ Dummy if active STC on SPS } & \multicolumn{2}{|c|}{ Dummy if active STC on TBT } \\
\hline & (1) & (2) & (3) & (4) \\
\hline \multirow[t]{2}{*}[\operatorname{ln}(\text{tariff}_{\mathrm{t}})-\operatorname{ln}(\text{tariff}_{\mathrm{t}-1})]{} & $-0.011^{*}$ & $-0.015^{\star}$ & $-0.032^{\star * \star}$ & $-0.041^{* \star *}$ \\
\hline & $(0.006)$ & $(0.008)$ & $(0.004)$ & $(0.004)$ \\
\hline \multirow[t]{2}{*}{$\operatorname{Ln}\left(\right.$ tariff $\left._{\mathrm{t}-1}\right)$} & $-0.015^{\star \star \star}$ & $-0.018^{\star \star \star}$ & $-0.049^{\star \star \star}$ & $-0.060^{\star \star \star}$ \\
\hline & $(0.001)$ & $(0.002)$ & $(0.001)$ & $(0.001)$ \\
\hline \multirow[t]{2}{*}{ Import Penetration $_{\mathrm{t}-1}$} & $-0.012^{\star \star \star}$ & $-0.013^{\star \star \star}$ & $-0.005^{\star \star \star}$ & $-0.003^{\star \star \star}$ \\
\hline & $(0.001)$ & $(0.001)$ & $(0.006)$ & $(0.000)$ \\
\hline Sample & Full sample & Agriculture & Full sample & Manufacturing \\
\hline First Stage Coefficient & $1.186^{\star \star \star}$ & $1.775^{\star \star \star}$ & $2.232^{\star \star \star}$ & 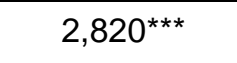 \\
\hline First stage F-stat & 12.47 & 9.46 & 33,61 & 60.57 \\
\hline Observations & 681330 & 381661 & 3340723 & 2946544 \\
\hline R-sq & 0.010 & 0.003 & 0.006 & 0.006 \\
\hline
\end{tabular}

Note: Robust standard error in parentheses. Country-Sector-Year fixed effects always included. Country pair specific controls always included are distance and GDPSUM.. ${ }^{*}{ }^{* *},{ }^{* *}$ indicate significance at the 10, 5 and $1 \%$ confidence level 
Table 11 - SPS and TBT concerns and Ad Valorem tariff change.

\begin{tabular}{|c|c|c|c|c|}
\hline \multirow[t]{2}{*}{ Dependent variable: } & \multicolumn{2}{|c|}{$\begin{array}{c}\text { Dummy if active STC on SPS has been } \\
\text { raised over the period }\end{array}$} & \multicolumn{2}{|c|}{$\begin{array}{c}\text { Dummy if active STC on TBT has beer } \\
\text { raised over the period }\end{array}$} \\
\hline & (1) & (2) & (3) & (4) \\
\hline$\left[\ln \left(\operatorname{tariff}_{\mathrm{t}-1}\right)-\ln \left(\right.\right.$ tariff $\left.\left._{\mathrm{t}-2}\right)\right]$ & $\begin{array}{l}-0.019 * \star \\
(0.009)\end{array}$ & $\begin{array}{c}-0.0185^{\star} \\
(0.009)\end{array}$ & $\begin{array}{c}-0.019 * \star \star \\
(0.007)\end{array}$ & $\begin{array}{c}-0.019 \star \star \star \\
(0.007)\end{array}$ \\
\hline $\operatorname{Ln}\left(\right.$ tariff $\left._{\mathrm{t}-2}\right)$ & $\begin{array}{l}-0.007 \\
(0.007)\end{array}$ & $\begin{array}{l}-0.007 \\
(0.007)\end{array}$ & $\begin{array}{c}-0.020 \star \star \star \\
(0.005)\end{array}$ & $\begin{array}{c}-0.022^{\star \star \star} \\
(0.005)\end{array}$ \\
\hline Import Penetration & & $\begin{array}{c}0.003 \\
(0.002)\end{array}$ & & $\begin{array}{c}-0.009 * \star \star \\
(0.001)\end{array}$ \\
\hline Sample & & & & \\
\hline Exporter-Product-Year FE & yes & yes & yes & yes \\
\hline Importer-Product-Year FE & yes & yes & yes & yes \\
\hline Country Pair controls & yes & yes & yes & yes \\
\hline Observations & 76,298 & 76,298 & 386,670 & 386,670 \\
\hline R-sq & 0.848 & 0.848 & 0.635 & 0.635 \\
\hline
\end{tabular}

Note: Robust standard error in parentheses. Country pair specific controls are distance and GDPSUM.*, ${ }^{* *},{ }^{* *}$ indicate significance at the 10 , 5 and $1 \%$ confidence level 


\section{References}

Bandyopadhyay S. And S. Roy (2011), "Political Economy Determinants of nonagricultural Trade Policy", Federal reserve Bank of Saint Louis Review, 93(2), pp.89-104.

Beverelli, C., Boffa, M. and A. Keck (2014) "Trade Policy Substitution: Theory and Evidence from Specific Trade Concerns”, WTO Staff working paper ERSD-2014-18.

Cadot, O., Disdier, A.-C. and Fontagné, L. (2014), "North-South Standards Harmonization and International Trade", World Bank Economic Review, forthcoming.

Chen, M.X., Otsuki, T and J.S. Wilson (2006), "Do standards matter for export success?", Policy Research Working Paper Series 3809, The World Bank.

Crivelli P. and J. Gröschl (2012), "The Impact of Sanitary and Phytosanitary Measures on Market Entry and Trade Flows", CESifo Working Papers 136.

De Sousa J., T. Mayer and S. Zignago (2012), "Market Access in Global and Regional Trade", Regional Science and Urban Economics, 42(6), pp. 1035-1052.

Disdier, A.-C., Fontagné, L. and Mimouni, M. (2008), "The Impact of Regulations on Agricultural Trade: Evidence from the SPS and TBT Agreements", American Journal of Agricultural Economics, 90(2), pp. 336-350.

Fontagné L., G. Orefice, R. Piermartini and N. Rocha (2015), "Product Standards and Margins of Trade: firm level evidence", Journal of International Economics, vol. 97(1), pp. 29-44.

Guimbard, H., Jean, S., Mimouni, M. \& Pichot, X. (2012), "MacMap-HS6 2007, an exhaustive and consistent measure of applied protection in 2007", International Economics, Q2, pp. 99-122.

Horn, H., P. C. Mavroidis and A. Sapir (2010), "Beyond the WTO? An Anatomy of EU and US Preferential Trade Agreements", The World Economy, 33(11), pp. 1565-1588.

Kee, H. L., Nicita, A. and Olarreaga, M. (2009), "Estimating trade restrictiveness indices", Economic Journal, 119(534), pp. 172-199.

Maertens, M., L. Driers, F.A. Dedehouanou, and J.F.M. Swinnen (2007), "High-Value Supply Chains, Food Standards and Rural Households in Developing Countries", in J.F.M. Swinnen (eds), Global Supply chains, Standards and the Poor, Wallingford: Cabi Publishing.

Maertens, M. and J.F.M. Swinnen (2009), "Trade, Standards, and Poverty: Evidence from Senegal", World Development, 37(1), pp.179-192. 
Mansfield E. and M. Busch (1995), "The Political Economy of Non-tariff barriers: a crossnational analysis", International Organization, 49(4), pp. 723-749.

Moore, M.O. and M. Zanardi (2011) "Trade Liberalization and Antidumping: is There a Substitution Effect?", Review of Development Economics, 15, pp.601-619.

Ray E.J. (1981), "The Determinants of Tariff and Nontariff Trade Restrictions in the United States", Journal of Political Economy, 89(1), pp. 105-121.

Wei G., J. Huang and J. Yang (2012), "Honey Safety Standards and its impact of China's Honey Exports", in Journal of Integrative Agriculture, 11(4), pp. 684-693.

World Trade Report (2011), "The WTO and Preferential Trade Agreements: from coexistence to coherence", WTO, Geneva.

World Trade Report (2012) "Trade and public policies: A closer look at non-tariff measures in the 21st century", WTO, Geneva.

Nom Prénom 


\section{Appendix A}

Table A1 - Countries used in the estimations sample.

\begin{tabular}{|c|c|}
\hline Sample of countries in SPS estimations & $\begin{array}{l}\text { Albania, Argentina, Armenia, Australia, } \\
\text { Bahrain, Barbados, Bolivia, Brazil, Canada, } \\
\text { China, Chile, Colombia, Costa Rica, Croatia, } \\
\text { Cuba, Dominican Republic, Egypt, El } \\
\text { Salvador, Europe, Gabon, Guatemala, } \\
\text { Honduras, Indonesia, India, Island, Israel, } \\
\text { Japan, Jordan, Korea, Kuwait, Malaysia, } \\
\text { Mexico, New Zealand, Norway, Omar, } \\
\text { Panama, Philippines , Qatar, Senegal, } \\
\text { Singapore, Suriname South Africa, } \\
\text { Switzerland, Thailand, Trinidad and Tobago, } \\
\text { Turkey, Ukraine, Uruguay, United States, } \\
\text { Venezuela. }\end{array}$ \\
\hline Sample of countries in TBT estimations & $\begin{array}{l}\text { Bahrain, Brazil, Canada, Chile, China, } \\
\text { Colombia, Ecuador, Egypt, Europe, } \\
\text { Indonesia, India, Israel, Japan, Korea, } \\
\text { Kuwait, Moldova, Mexico, Malaysia, New } \\
\text { Zealand, Peru, Philippines, Qatar, South } \\
\text { Africa, Switzerland, Thailand, Tunisia, } \\
\text { Turkey, United States, Uruguay, Venezuela, } \\
\text { Vietnam. }\end{array}$ \\
\hline
\end{tabular}

NOTE: EU-27 here is considered as a single country as it plays as a single actor at the SPS/TBT committee of the WTO. 
Table A2 - In sample descriptive statistics SPS regressions

\begin{tabular}{lccccc}
\hline & Obs & Mean & Std Dev & Min & Max \\
\hline SPS dummy & 384699 & 0.039 & 0.194 & 0 & 1 \\
{$[\ln ($ tariff $)-\ln ($ tariff } & & & \\
Ln(tariff $)]$ & 384699 & -0.002 & 0.045 & -2.604 & 2.721 \\
Import Penetration & 384699 & 0.079 & 0.128 & 0 & 1 \\
& 384699 & 0.082 & 0.181 & 0 & 1 \\
\hline
\end{tabular}

Table A3 - In sample descriptive statistics TBT regressions

\begin{tabular}{lccccc}
\hline & Obs & Mean & Std Dev & Min & Max \\
\hline SPS dummy & 2956725 & 0.017 & 0.131 & 0 & 1 \\
{$\left[\ln \left(\right.\right.$ tariff $\left._{\mathrm{t}}\right)-\ln \left(\right.$ tariff $\left.\left._{\mathrm{t}-1}\right)\right]$} & 2956725 & -0.003 & 0.030 & -2.774 & 2.663 \\
$\mathrm{Ln}($ tariff & & & & \\
Import $)$ & 2956725 & 0.069 & 0.074 & 0 & 2.776 \\
& 2956725 & 0.051 & 0.128 & 0 & 1 \\
\hline
\end{tabular}


Table A4 - SPS and TBT concerns on highly protected sectors.

\begin{tabular}{|c|c|c|c|c|c|c|c|c|}
\hline \multirow[t]{2}{*}{ Dependent variable: } & \multicolumn{4}{|c|}{ Dummy if active STC on SPS } & \multicolumn{4}{|c|}{ Dummy if active STC on TBT } \\
\hline & (1) & (2) & (3) & (4) & (5) & (6) & (7) & (8) \\
\hline \multirow[t]{2}{*}[\operatorname{ln}(\operatorname{tariff}_{\mathrm{t}})-\operatorname{ln}(\text{tariff}_{\mathrm{t}-1})]{} & $-0.013^{\star \star \star}$ & $-0.013^{\star \star \star}$ & $-0.011^{\star}$ & $-0.011^{\star}$ & $-0.020^{\star \star \star \star}$ & $-0.020^{\star \star \star \star}$ & $-0.017^{\star \star \star}$ & $-0.016^{\star \star \star}$ \\
\hline & $(0.005)$ & $(0.005)$ & $(0.006)$ & $(0.006)$ & $(0.003)$ & $(0.003)$ & $(0.003)$ & $(0.003)$ \\
\hline \multirow[t]{2}{*}{$\operatorname{Ln}\left(\right.$ tariff $\left._{\mathrm{t}-1}\right)$} & -0.003 & -0.003 & -0.001 & -0.001 & 0.000 & 0.000 & $-0.020^{\star \star \star}$ & $-0.020 * \star \star$ \\
\hline & $(0.005)$ & $(0.005)$ & $(0.006)$ & $(0.006)$ & $(0.004)$ & $(0.004)$ & $(0.006)$ & $(0.006)$ \\
\hline \multirow[t]{2}{*}{ Import Penetration } & & $-0.005^{\star \star \star}$ & & $-0.004^{\star \star}$ & & 0.000 & & 0.001 \\
\hline & & $(0.001)$ & & $(0.002)$ & & $(0.001)$ & & $(0.001)$ \\
\hline Sample & \multicolumn{2}{|c|}{ If tariff $f_{(t-1)}>$ median } & \multicolumn{2}{|c|}{$\begin{array}{c}\text { If tariff }(t-1)>\text { median and } \\
\text { Agriculture }\end{array}$} & \multicolumn{2}{|c|}{ If tariff $(t-1)>$ median } & \multicolumn{2}{|c|}{$\begin{array}{c}\text { If tariff } f_{(t-1)}>\text { median and } \\
\text { Manufacturing }\end{array}$} \\
\hline Exporter-Product-Year FE & yes & yes & yes & yes & yes & yes & yes & yes \\
\hline Importer-Product-Year FE & yes & yes & yes & yes & yes & yes & yes & yes \\
\hline Country Pair controls & yes & yes & yes & yes & yes & yes & yes & yes \\
\hline Observations & 296,443 & 296,443 & 161,250 & 161,250 & $1,517,295$ & $1,517,295$ & $1,357,652$ & $1,357,652$ \\
\hline R-sq & 0.358 & 0.358 & 0.384 & 0.384 & 0.630 & 0.630 & 0.657 & 0.657 \\
\hline
\end{tabular}

Note: Robust standard error in parentheses. Country pair specific controls are distance and GDPSUM.*, ${ }^{\star \star}$, ${ }^{\star \star *}$ indicate significance at the 10,5 and $1 \%$ confidence level. 
Table A5 - Instrumental Variable regressions using country-product-year fixed effects.

\begin{tabular}{|c|c|c|c|c|}
\hline \multirow[t]{2}{*}{ Dependent variable: } & \multicolumn{2}{|c|}{ Dummy if active STC on SPS } & \multicolumn{2}{|c|}{ Dummy if active STC on TBT } \\
\hline & (1) & (2) & (3) & (4) \\
\hline \multirow[t]{2}{*}[\operatorname{ln}(\operatorname{tariff}_{\mathrm{t}})-\operatorname{ln}(\operatorname{tariff}_{\mathrm{t}-1})]{} & -0.019 & $-0.026^{\star}$ & $-0.024^{\star \star \star}$ & $-0.038^{\star \star \star}$ \\
\hline & $(0.011)$ & $(0.015)$ & $(0.006)$ & $(0.006)$ \\
\hline \multirow[t]{2}{*}{$\operatorname{Ln}\left(\right.$ tariff $\left._{t-1}\right)$} & $-0.048^{\star \star *}$ & $-0.060^{\star * \star}$ & $-0.069 * * *$ & $-0.097^{\star \star *}$ \\
\hline & $(0.005)$ & $(0.007)$ & $(0.002)$ & $(0.003)$ \\
\hline \multirow[t]{2}{*}{ Import Penetration $_{\mathrm{t}-1}$} & $-0.013^{\star \star \star}$ & $-0.013^{\star \star \star}$ & $-0.008^{\star \star \star}$ & $-0.005^{\star \star \star}$ \\
\hline & $(0.001)$ & $(0.001)$ & $(0.000)$ & $(0.001)$ \\
\hline Sample & Full sample & Agriculture & Full sample & Manufacturing \\
\hline First Stage Coefficient & $1.181^{\star \star \star}$ & $1.158^{\star \star \star}$ & $2.777^{\star \star \star}$ & $3.669 * \star \star$ \\
\hline First stage F-stat & 5.31 & 4.05 & 7.86 & 12.8 \\
\hline Observations & 667,640 & 370,323 & 3317812 & 2934922 \\
\hline$R-s q$ & 0.010 & 0.003 & 0.006 & 0.006 \\
\hline
\end{tabular}

Note: Robust standard error in parentheses. Country-Products-Year fixed effects always included. Country pair specific controls are distance and GDPSUM. ${ }^{\star \star *},{ }^{\star \star \star}$ indicate significance at the 10, 5 and 1\% confidence level 
Figure A1 - Average tariff change and number of STCs on SPS in the period 1996-2010.

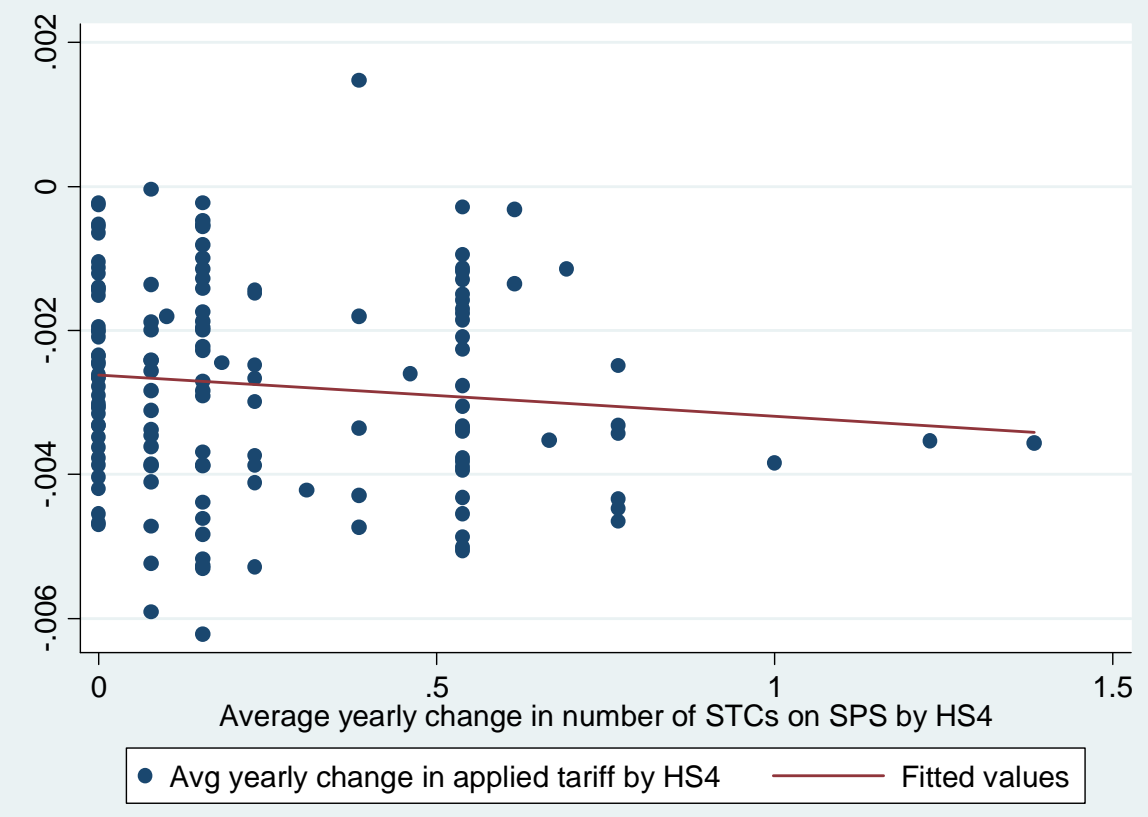

Source: WTO, STC dataset and TRAINS.

Figure A2 - Average tariff change and number of STCs on TBT in the period 1996-2010.

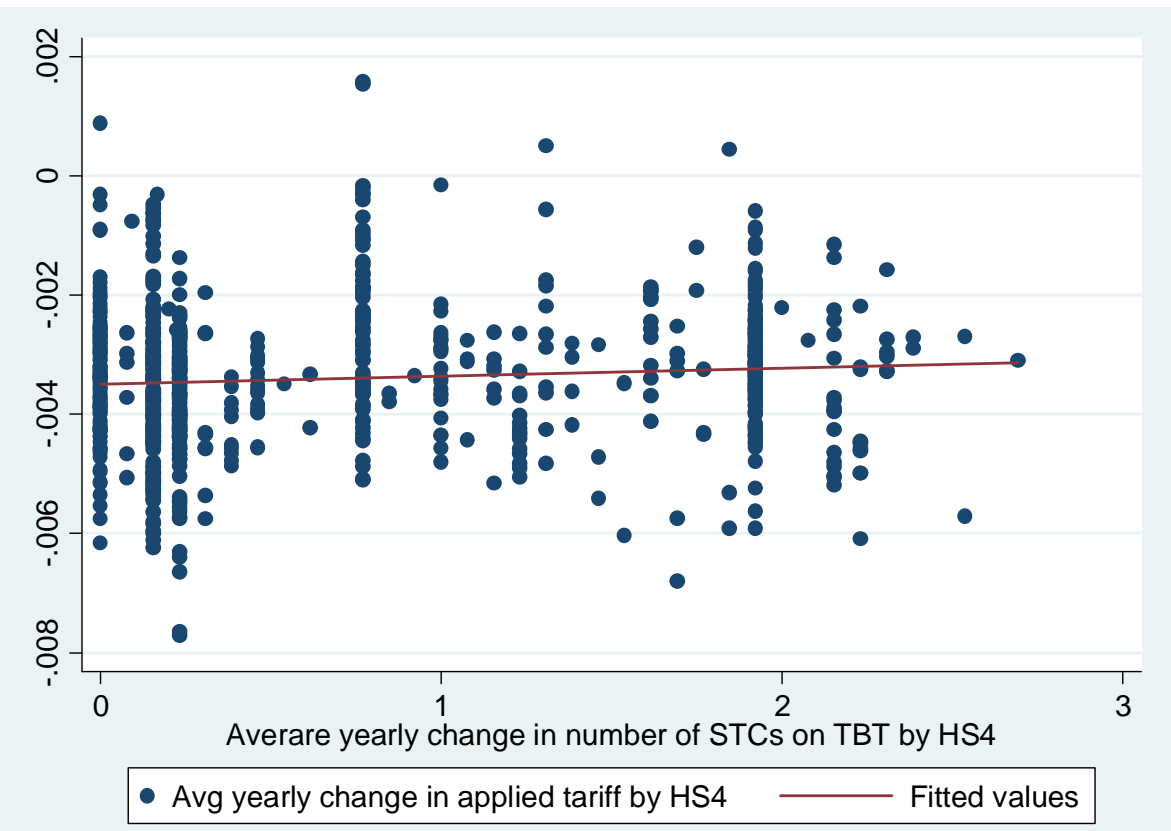

Source: WTO, STC dataset and TRAINS. 